\title{
Representing the family: how does the state "think family'?
}

\author{
James Cornford, Susan Baines and Rob Wilson
}

Over the last decade the family and family-centred policies and practices have received increasing attention within the public service agenda, culminating in the emphatic instruction to 'think family' individually, collectively and institutionally. This has occurred at a time when the sociology of the family has increasingly emphasised the difficulties of thinking family in a coherent way. In this article we explore this agenda through an examination of the representational tools with which public service professionals and managers have been recently equipped.We conclude by questioning the adequacy of these tools for effectively representing family relations.

\section{Introduction: think family!}

[W]e find ourselves in the middle of a global revolution in which people are taking apart, and renegotiating the apparently eternal laws of what used to be straightforwardly known as "the family". (Beck and Beck-Gernsheim, 2004: 499)

Families, in whatever form they take, are the bedrock of our society. (DCSF, 2009: 2; emphasis added)

The Government believes that strong and stable families of all kinds are the bedrock of a strong and stable society. (HM Government, 2010: 19; emphasis added)

Public authorities in Britain have traditionally 'fought shy of intervening in the private sphere' (Milner, 2010: 5; Lewis, 2007). In the first decade of the 21st century however, the loose cluster of relationships and interactions that we group under the title of family became increasingly central objects of government intervention (Gillies, 2005; Clarke and Hughes, 2010). The New Labour government legislated 'to encourage what are seen as positive family practices and discourage other practices' (Milner, 2010: 5). Right across government, in relation to services for children and for adults, agencies and professionals have been told to 'think family' (Cabinet Office Social Exclusion Task Force, 2007, 2008).

Interest in 'families' has survived the demise of New Labour and has been taken up, albeit with some different emphases, by the coalition government that emerged from the 2010 General Election. The coalition has declared that a family-focused way of working continues to be a core element of the 'Big Society' agenda and expressed commitment to a 'whole family' approach to families with multiple and complex problems (Kendall et al, 2010). Social services, health and education are recruiting 'the family' as allies in the planning and delivery of services, placing new

Key words: family $\bullet$ representation $\bullet$ information sharing $\bullet$ records 
responsibilities on families for everything from care planning to managing antisocial behaviour. The imperative to provide 'joined-up' services is bringing different public services into contact with each other around the family. Unsurprisingly, each professional group has its own ways of defining, recording and envisaging 'family'. These changes have made family relationships an increasingly important issue for public service managers and professionals and, simultaneously, problematised them.

These developments are taking place against a background of lack of agreement about how to define and delineate 'the family' (or families), about how many 'forms' or 'kinds' of family there are (or should be), about which families need, can benefit from or deserve support, and about how that support should be planned, coordinated, delivered and evaluated. While politicians vie with each other to represent 'Britain's hardworking families' (Wheeler, 2005), families are framed in a number of other ways - for example as 'strong families' (Cameron, 2011), 'fragile families' (Holmes and Kiernan, 2010), 'families with multiple problems' (York Consulting, 2011) or 'families at risk' (DCSF, 2009). Definitions are important because they do not 'merely describe' an external reality but also shape that reality. As Bourdieu (1996: 21) has put it, 'in the social world, words make things, because they make the consensus on the existence and the meaning of things, the common sense, the doxa, accepted by all as self evident'. The family can, then, be seen as a 'well-founded fiction', but a fiction with real effects:'a powerful, performative discourse, which has the means of creating the conditions of its own verification and therefore its own reinforcement' (Bourdieu, 1996: 20, 25).

In this article we pose the question: How can public services as institutions, and the professionals that they employ, 'think family'? Our way into this question is through the material means for recording, sharing and interpreting information about family relationships. Records systems and case files contain a range of formally and informally encoded information concerning family relations, from legal documents, through individual or case records, to photographs and video material.These representations, and the practices that generate, manage and interpret them, are at the heart of our arguments. We contrast the formal 'grammar' of family relationships (Levi-Strauss, 1964), which has tended to inform attempts to instantiate family in services' information systems, with richer notions of representation as a collective achievement (Dourish, 2004), and one that not only describes aspects of the world but also actively makes those aspects thinkable (Bloomfield andVurdubakis, 1997). Through this conceptual lens, we review some of the ways in which recent investments in complex information systems have shaped the capacity of public services to 'think family'. If we accept Bourdieu's (1996: 21) contention that 'the family is the product of a labour of institutionalisation, both ritual and technical', then this article is ultimately concerned to explore this technical aspect of the institutionalisation of the family as it has developed in public services in England in the past decade.

The rest of this article is organised as follows. To set the scene we expand on recent family interventions in public policy and reflect on the paradox that, as these have expanded, families have come to be seen as increasingly complex, difficult to define and, indeed, unthinkable. Then we turn to the nature and limitations of the resources (information systems tools) that have been provided to enable public services to individually and collectively 'think family'. In the following section we examine 
three examples of such systems and their representational schemas. In a penultimate section we discuss evidence from these examples that information practices and systems shape the kind of families that it is possible for public services to recognise and support. Our concluding section offers tentative suggestions for new approaches to representations that could advance 'thinking family' in more complex and subtle ways than have so far been possible.

\section{Policy and the family: bedrock or problem}

The ascendance of family in English social policy, most dramatically symbolised by the creation in 2007 of the Department for Children, Schools and Families (DCSF), touches on a wide range of policy areas, from education and health to criminal justice and pensions. (Although the name reverted to the Department for Education in 2010, there is still a Minister of State for Children and Families.) The notion of partnership between the state and families was established in the Children Act 1989 (DH et al, 2000). This has been slowly and unevenly translated into a range of programmes. For example, a fundamental premise of the Sure Start programme, an area-based early intervention for the under-fives, was that better outcomes for children could not be achieved by focusing on the child alone but needed the active participation of parents (Lewis, 2011). The Childcare Act 2006 made health services and Jobcentre Plus statutory partners in providing services through children's centres, widening the range of agencies drawn into family-related service provision (Lewis, 2011). The emphasis on family as a context for intervention has also been complemented by the idea of the family as an ally or co-producer of services and solutions. For example, a family group conference attempts to support families, including extended family members, in finding their own solutions to problems rather than relying on professionals (Schmid and Pollack, 2009). All this points towards a more family-focused approach to social policy for children but the trend should not be overstated. Engaging family members in planning is seen as high risk by many professionals (Morris, 2011). Hall et al (2010:397-8) contend that within social work, increased interest in the views and rights of children has 'subtly but significantly shifted from a focus on the family to one which is concerned directly with childhood vulnerability and well-being, and upholding parental responsibility'.

Although family policy, as it developed in the UK in the late 1990s, was dominated by concerns with children, parenting and child poverty (for example through the Every Child Matters agenda, Sure Start and Family Tax Credits), there has been growing awareness that adults have families too. This development was most clearly signalled by the publication in 2007 of Think family by the Cabinet Office Social Exclusion Task Force. Concerns such as work-life balance, the emergence of new family forms and the role of families in the New Deal for Carers, especially carers of elderly relatives, extended the scope and balance of family policies. For example, the DCFS (2009: 2) Think family toolkit listed '[m]others, fathers, brothers, sisters, grandparents, step family and extended family'. If the family agenda has spread beyond an initial focus on children, it also expanded beyond the confines of children's services. The Think family toolkit identified a 'national programme of reform and culture change which involves all schools and children's services, the NHS, Jobcentres Plus, police, probation and prisons' (DCSF, 2009: 2). 
The family is a notoriously complex and contested concept, a compound of social, legal and biological relationships. Recent developments in legal frameworks, reproductive and related technologies and social norms and expectations have expanded the range of possible and legitimate family relations. Notions of family are not stable in time and our understandings of family are changing in a number of ways. Migration and movement, for example, have led to greater mixing of different models of the family in many locations (Therborn, 2004). Legal changes have created new family roles and identities. For example, the Civil Partnership Act 2004 created the new legal category of 'civil partner', an individual who enjoys most of the legal rights of conventional married individuals (eg, in relation to wills, the administration of estates and family provision).

New reproductive technologies and bioscience have also created new categories of relationship. As Strathern (1996:47) has noted, 'developments in new technologies have made newly explicit the possibility of choosing whom and what one desires to call family'. Reproductive techniques such as in vitro fertilisation (IVF) and gender reassignment surgery have dramatically changed certain kinds of family relationships and created new ones. The prevalence of IVF, coupled with increasingly easy access to information about donors, for example, has increased the number of genetic half-brothers and half-sisters (see, for example, Freeman et al, 2009), while gender reassignment can create a range of stresses and issues for other family members (White and Ettner, 2007). Such novel choice as is available may, of course, be illusory or tightly circumscribed by its framing in relation to idealised nucleated, neolocal, heterosexual norms (Mulkay, 1994; Wilson 2007), but new classes of individuals - 'test-tube babies' for example - and new relationships - 'child-donor' for example - have come into regular, popular discourse. These technical, legal and social innovations have expanded and diversified what is possible within families and family relationships.

Sociological perspectives tend to stress fluidity and ambivalence in family relations (Cheal, 1991; Luescher and Pillemer, 1998; Connidis and McMullin, 2002; Williams, 2004). 'Family' has come to refer 'not to a single empirical reality' but rather to multiple 'layers of meaning' (Smart, 2005: 542). Family formation and kin relationships appeared to take an increasingly bewildering variety of forms in the later 20th century (Cheal, 1991), although historical research suggests that a diversity of living arrangements labelled 'family' had existed for two centuries (Gittins, 1985). Feminist insights have inspired interest in family practices (rather than family forms) and encouraged usage of 'family' as an adjective or a verb (Morgan, 2011; Ribbens McCarthy and Edwards, 2011). For some theorists the term 'family' is so infused with folk notions of the normative, heterosexual, lifelong conjugal unit that academics should abandon it (Scanzoni, 1987). Smart (2007) prefers the more expressive and inclusive vocabulary of 'intimacy' and 'personal life'. Edwards and Gillies (2012) and Ribbens McCarthy (2012), in contrast, robustly defend the retention of family in contemporary studies.

In their review of developments in thinking about the family, Beck and BeckGernsheim (2004: 512) summarise much of this new thinking as follows:

Individualized constellations of community and family can no longer be defined and integrated through pregiven norms, values and hierarchies; 
rather, they must be defined through risky freedoms, and hence through nonintegration. Accordingly, we must consider the constitutive legal, political, and economic norms of risky freedoms.

What this individualisation of the family essentially means is that the perceived family is the family structure, and that consequently the meaning of family varies individually between members within the family as well as between 'families' (Beck and Beck-Gernsheim, 2004: 508). Finch and Mason (1993), in their classic exploration of responsibility in family relationships, asked whether there was 'a clear consensus among the British population about what kind of responsibilities people should acknowledge'. Their unequivocal answer was 'no' (Finch and Mason, 1993: 14).Yet simply because there is not a general agreement about family responsibilities, does not mean that these responsibilities do not exist or cannot be recorded. Finch and Masons' central argument, summed up in the title of their book, is that family responsibilities are negotiated within each family over time.

In this new context, characterised by an increasing range of possible types of family, and an increasing ambiguity in family relationships and asymmetrical family relations, the problem of consistently representing family relations has arisen. Historically, structural anthropology reconceived the problem, after the manner of (structural) linguistics. Levi-Strauss, for example, argued that 'the problem can be formulated in the following fashion: in another order of reality the phenomena of kinship are phenomena of the same type as linguistic phenomena' (Levi-Strauss, 1964: 41; emphasis in original). This implied a kind of 'grammar' of family relationships based on three structural oppositions that, he claimed, were fundamental - consanguinity (brother/ sister), marriage (husband/wife) and lineage (parent/child). Such structural elements enable a complex set of relations to be built, but fail to establish the content or meaning of such relationships. For example, it is possible to identify cousins from this schema on the basis of shared (grand)parentage. What is not possible is to say what being a cousin means for the individuals involved, how this relationship affects their behaviour (if at all) and thus its significance for social policy.

However, if the state is to support families and recruit them as allies in achieving social objectives, then it must be able to produce some kind of representation of the family. Codifying and classifying the family is thus a significant activity for official statisticians and demographers - and for academics working on behalf of the state - as they grapple with the definition of the family in order to measure and classify. Constructs such as the Standard North American Family - the SNAF - have arisen from these efforts, but have been strongly criticised as ideological (Smith, 1993). Families overlap with other statistical and administrative constructs, in particular the 'household'. For example, the United States Census Bureau distinguishes between 'family', 'family group' and 'family household' as well as 'related' and 'unrelated' 'subfamilies', highlighting the intricate relationship between potentially spatially dispersed and mobile families and spatially concentrated and relatively fixed households.

Technologies of e-government are increasingly significant in constructing the representations of service users, and other aspects of the service environment. Computer scientists, software engineers and system architects with the problem of delivering the systems to support the workings of public services have the practical 
problem of creating representations of family relationships within the information systems they create. There is a strong tendency for the software engineers and the informatics community to construct their schemas on the basis of structuralist oppositions akin to those of Levi-Strauss. However, as we have argued previously, this approach paints far too stark and unsubtle a picture of family, one that masks the softer relational notions from the broader social science and social care practice literatures. Thus, systems have to capture not just established legal, biological and social family relations but also multiple perceptions and interpretations of those relations.

\section{Representation of users, citizens and families}

Our apprehension, description, and classification of the physical world depend on the technologies that make these activities possible. In other words, the world is constituted in virtue of the technologies of representation available. (Woolgar, 1995: 164; cf Bowker and Star, 2002)

Computation is fundamentally about representation. (Dourish, 2004: 137)

The instruction to 'think family' applies at a range of levels. First, it applies to the individual public service professional in their daily work. Second, it applies to the collective team of professionals in their work on individual cases. Third, it applies to the institutional managers of public services in the planning, monitoring and evaluation of service provision. Finally, and most importantly, it applies to the interagency partnerships that deliver much family-related policy. In all these cases, but in particular in the last three, this thinking is a collective or shared enterprise, what anthropologists and information scientists have come to call 'distributed cognition' (Hutchins, 1995; Dourish, 2004). From this point of view, cognition is a collective achievement that occurs through interaction between individuals and between individuals and a range of 'objects' that undertake representational and other kinds of work for the collective. There is a key role for shared or sharable representations maps, charts, notes, records - in the process of distributed cognition. These frequently act as boundary objects, facilitating the fruitful interaction of actors working on different parts or aspects of a complicated or complex problem (Star and Griesemer, 1989). Making things thinkable thus involves making good things (representations) with which to think. Is this happening with respect to family?

Representations are often seen as a passive or descriptive record of the facts literally the re-presentation of material. However, we have long been aware that representations can also been seen as much more active and constructive in relation to their referents. From this point of view, they are attempts at what Bloomfield and Vurdubakis (1997) have called 'worldmaking'. Writing in the context of organisational information systems, they argue that:

representational practices such as information requirements analysis, data modelling and the like, are conceived and employed as technologies of control. They are to be understood as efforts at "worldmaking" ... as attempts to institute particular versions of the organization, its members and their activities. Such representational practices create a "presence" for a particular 
set of representational facts, defining their range of possibilities and rendering them visible to the participants in the organizing process.... They can thus be seen as a means of rendering the "organization" into a stable, observable, or otherwise credible entity. (Bloomfield and Vurdubakis, 1997: 641)

What is true of the organisation is true also of its various members and interlocutors. Record systems - formal representations of current and past affairs - and the recording and interpretative practices that surround them, help to stabilise a range of individual and collective identities, their apparent neutrality - and even boringness hiding their political and constitutive nature (Prince, 1996). For example, as Halford et al (2010: 211) have argued in relation to electronic patient records, "changing the record-keeping system is not simply a case of improving the "copy of events" or "repository of facts," but may also disrupt previously embedded forms of work and organisation'.

In the design of e-government technologies, there is much rhetorical attention played to ensuring that services are customer focused. E-government has sought to remodel the way in which the state and public service interact with their 'users'. This has often taken on private sector models that emphasise the individual as public service customer, as citizen or as service user (Clarke et al, 2007; King and Cotterill, 2007; Richter and Cornford, 2008) or large aggregates such as 'the community' or 'the public'. Services are remodelled around a representation of the service user as 'the customer', adapting private sector discourses and related techniques and technologies such as customer relationship management. The construction of this representation is necessarily selective; in general it envisages users as individuals, as individualistic, time pressured and as characterised by means-end rationality. Yet these representations clash with other models of service users, for example as citizens, as members of a deliberative public or as members of a specific community of interest, activity or fate.

The literal nature of information technology systems, with their need for constant disambiguation, renders these dilemmas increasingly visible. The emphasis on information sharing as the key to effective multi-agency working has also placed information systems at the heart of attempts to 'join up' services around the family. And, of course, where service users (individual and collective) are recruited to the task of co-production of services, then they are not just the object of information systems but can also become active users of the systems. The complexities of admitting individual service users to the record systems of individual services become multiplied when more than one service is involved and yet more complex when access is to be granted to an amorphous entity such as 'the family'. Thus, the complexity and uncertainty indicated in the confusing array of terms for the individual user (and co-producer) of public services - citizen, client, patient, customer, service user become significantly more contested and difficult to agree when trying to comply with policy imperatives to work with 'family'.

Given this complexity, it is not surprising that the family and family relationships, while a constant feature of public sector management systems, have not had much status within the development of e-government or more recent transformational government in the UK. Hall et al (2010:398) argue that an unintended consequence of child-centredness is that information systems 'disaggregate and fragment the 
family'. The dominant 'family' concern in the design of information systems, however, has been child protection, following on from theVictoria Climbie and Baby P cases and subsequent reviews (Laming, 2003, 2009). Understandably these concerns have shaped the construction of many child-related record and case management systems within the frame of a family-as-risk perspective. An important recent article in this journal (6 et al, 2010; see also Munro, 2011) has argued that these risk-based approaches to information sharing can act to increase risk by seeking to curtail the professional judgement of practitioners on the ground.

\section{Examples: the Common Basic Data Set, the e-GIF and the ICS}

To illustrate our argument we want to examine the representation of family in three recently developed public service initiatives. In each case, we want to highlight the kinds of family relationships that are recorded and those that are not recorded or harder to record, any hierarchies, implicit or explicit, for family forms or relationships and the implicit and explicit assumptions that underlie the terms and classifications used.

The first of these is the Common Basic Data Set (CBDS), which has been used for gathering information from schools and other children's providers and transferring it within the domain of education and children's services. The second is the electronic Government Interoperability Framework (e-GIF), which includes a set of categories and classification that are designed to facilitate data sharing across government domains. Finally, we examine the Integrated Children's System (ICS), developed under the auspices of the Department of Health and implemented by local authorities, which was designed to facilitate the improved sharing of information about children and young people among relevant agencies.

\section{CBDS}

The Common Basic Data Set (CBDS) was developed by the DCFS. Although it is being absorbed into the wider frameworks developed by the Information Standards Board (www.escs-isb.org.uk/), its history and development cast light on the processes by which representational standards emerge. 'The CBDS provides a standard for data used in software systems for management information in schools, LAs [local authorities], other children's institutions, the DCSF and other Government bodies' (www.teachernet.gov.uk/management/ims/datamanagement/cbds/background). It developed as a set of data definitions and coding sets - building on existing practice - instead of being derived from a comprehensive data model. It aims to provide a full set of definitions from which schools and other agencies dealing with children can select those that are useful. For the purposes of this article, we are using the May 2010 version (www.teachernet.gov.uk/_doc/14812/CommonBasicDataset_ version28May2010.xls).

The CBDS contains a range of information concerning family relations. For example, one data item is 'type of family' for which the CBDS provides the following five options: single parent; two adults; foster parents; in residential care; unknown. Interestingly, the category of two adults does not specify any particular legal or 
biological family relationships - these adults could be grandparents, civil partners or any other pair of adults - while a single adult caring for a child is automatically a parent and the legal statuses of foster parents and the state ('in residential care') are made clear.

The CBDS also casts light on the cultural complexity of family relations. There are several codes related to family naming. For example, the child's surname is defined as 'full legal surname (derived from family, clan or marital association) of the child (as written)'. This needs to be complemented by a 'full legal family name', which is glossed as ' $[\mathrm{t}$ ] hat part of a person's name which is used to describe family, clan, tribal group, or marital association'. These fields are supplemented with fields for 'former family name' and 'preferred family name'. Further fields accommodate distinctions between family and public first names.

The CBDS contains categories for mapping children's relations to adults.A range of such relationships are defined (see Box 1) and parental relationships are distinguished from other kinds of relationship ("Parent" and "parental responsibility", the documentation notes, "are defined in the Guidance on Schools, "Parents" and "Parental Responsibility"'). Parenting - in various forms - dominates and other kinds of family relations are relegated to 'other family member' and 'other relative'. Family and family relations (or the lack of them) are also strongly represented in the Primary Need codes (see Box 2). Again, it is parenting that dominates with codes for 'parental disability/illness' and 'absent parenting' but these are supplemented by codes for 'family dysfunction' and 'family in acute stress'.

Most data items in the CBDS refer to individual children and their relations to specific adults. However, sibling relations are occasionally recognised, but from a risk perspective, for example 'sibling on the child protection register'.

\section{Box I: CBDS contact relationships (v2.0)}

- Carer

- Childminder

- Doctor

- Father

- Foster father

- Foster mother

- Head teacher

- Mother

- Other contact

- Other family member

- Other relative

- Religious/spiritual contact

- Social worker

- Step father

- Step mother

- Teacher

Source: www.teachernet.gov.uk/_doc/I48I2/CommonBasicDataset_version28May20I0.xls 


\section{Box 2: CBDS Primary Need codes}

- Abuse or neglect

- Child's disability/illness

- Parental disability/illness

- Family in acute stress

- Family dysfunction

- Socially unacceptable behaviour

- Low income

- Absent parenting

- Cases other than Children In Need

- Not stated

Source: www.teachernet.gov.uk/_doc/I48I2/CommonBasicDataset_version28May20I0.xls

What is clear is that the dataset struggles to encompass a range of family relationships, is strongly influenced by a risk model of family and is dominated by legal and regulatory relationships and categories. Notably, the voice of the child, or of his or her family members, is absent.

\section{The e-GIF}

The electronic Government Interoperability Framework (e-GIF) is a set of policies and standards to "enable information to flow seamlessly across the public sector and provide citizens and businesses with better access to public services' and is described on the Cabinet Office website as 'the technical cornerstone of the e-government policy for joining up the public sector electronically and providing modern, improved public services' (http://interim.cabinetoffice.gov.uk/govtalk/faqs/egif.aspx; see also Guijarro, 2007).

The e-GIF provides two digit codes for a range of family relationships (see Box 3). These codes are glossed as 'a value to represent the type of personal relationship that exists between two persons that is of interest to government'.

\section{Box 3: e-GIF person relationship type}

- $\quad 01$ Spouse

- 02 Partner

- 03 Parent

- 04 Next-of-kin

- 05 Guardian

- 06 Foster parent

- 07 Polygamous partner

- 08 Step parent

- 09 Child

- 10 Dependant

- II Non-dependant

Source: http://interim.cabinetoffice.gov.uk/govtalk/schemasstandards/e-gif/datastandards/relationship/ person_relationship_type.aspx 
This kind of list is, of course, analogous to the 'grammatical' approach proposed by Levi-Strauss (1964), although it provides only a subset of possible relationships that have been highlighted in the Think Family policy. For example, there is no direct provision for sibling, half-sibling, grandparent or cousin (although such relationships could be logically constructed from those provided).

The e-Gif also provides clear protocols for the verification of relationships. Focusing on code 03 (parent), the e-GIF shows a clear epistemological hierarchy:

- Level 0 - not verified

- Level 1 - CH1000 (notification that Child Benefit is in payment to this person)

- Level 2 - report from social worker or other recognised professional

- Level 3 - one of the following:

- full birth certificate

- adoption certificate

- birth certificate after adoption

- Level 4 - positive DNA [deoxyribonucleic acid] test result (source: http://interim. cabinetoffice.gov.uk/govtalk/schemasstandards/e-gif/datastandards/relationship/ person_relationship_type.aspx).

Beyond an unverified assertion, bureaucratic systems (Child Benefit) or the judgement of professionals provide added assurance. Higher levels of verification depend on some kind of formal legal registration. However, beyond even the law, the outcome of DNA tests is seen as giving the strongest verification.

\section{ICS: Integrated Children's System}

The Integrated Children's System (ICS) was developed to improve outcomes for children defined as being in need, under the Children Act 1989. The ICS is a set of forms, and associated processes, centrally designed and intended to provide a template for gathering and sharing information on children at a local authority level. These forms can be taken by system vendors and used to create ICS-compliant systems. A range of such systems have been built and evaluated (see, for example, Shaw et al, 2009; Hall et al 2010; White et al, 2009, 2010; Munro, 2011). The forms progress from relatively short items that capture basic information about all children deemed to be 'in need', to longer and more complex forms that relate to specific situations for a subset of children (eg, a case conference).

The ICS forms make extensive reference to family relations and to families. Form b (Referral and Information Record), for example, identifies the child's 'main carers' (cross-referenced to adult social services where records exist) and a separate entry for the child's parents ('if not main carers'). This form also attempts to capture information on other household members (whether family members or not) and on 'significant family members who are not members of the child's household'.

The family-as-risk perspective is strongly represented with sections of Form b noting whether the child or other children/young people in the household are on the child protection register. This risk perspective is developed over the subsequent forms. For example, Form c (Initial Assessment) is structured around the categories of the child's health, education, emotional and behavioural development, identity, 
family and social relationships, social presentation and self-care skills. For each of these, an assessment is made of the child's need and of the 'parenting capacity' of parents and/or carers. Detailed information on issues that might affect such capacity is also called for. This is glossed as follows: 'Research shows that the following are most likely to affect parenting capacity: physical illness; mental illness; learning disability; substance/alcohol misuse; domestic violence; childhood abuse; history of abusing children.' The form also notes that '[i]t is also important to record details of adults who might pose a risk of significant harm to the child/young person'. Other information gathered relate to 'family and other environmental factors that impact on the family', including 'family history and functioning', 'wider family' and 'family's social integration'.

The ICS forms are dominated by a model of the family as risk, but they do also include opportunity for some family members - children and parents/carers - to record their own concerns. Form c, for example, notes that 'The completed Initial Assessment and Plan should be discussed with the child/young person and their parents/carers' and that 'a copy should be provided to the child and appropriate family members, unless to do so would place the child/young person at risk of significant harm.'The form also contains space for children/young people and their parents/ carers to comment, explicitly highlighting any 'areas of disagreement'. By the time that we reach Form $\mathrm{f}$ (Initial Child Protection Conference Report), the forms are explicitly gathering 'expressed views, wishes and feelings' of the child/young person, of their parent(s)/main carers and of 'other significant family/household members where appropriate'.

\section{Discussion: the challenges of representation and negotiation}

What is striking about these examples is that:

- they retain a monological desire to capture and record 'the family' as a more or less restricted set of symmetrical relations (family relations being subordinated to the abstract grammar of categories and classifications);

- the model of family is dominated by intergenerational relations of parenting and caring

- the state's concerns with families, as revealed through these classifications, are heavily conditioned by a model of the family as a source of risk to children or as a (potentially incompetent) ally;

- until the state agencies have become intimately involved with the family (eg, through a case conference), there is little or no space for family members to take a more active role in representing their family relationships.

Let us take these points one at a time. First, in spite of the emergence of an impressive body of academic work that has stressed the ambiguous, asymmetrical and negotiated nature of family relations and the need for them to be performed, practised and displayed, the systems we have discussed appear to be locked into an outmoded picture of family relations. There is evidence of a clear hierarchical model in which apparently crisp categories of genetic science and the law are seen to trump the merely 'social' lived experience of family with all its indeterminacy and dynamics 
(Hall et al, 2010). To the extent that this is true, these systems limit the capacity of public services to think family in a rich and insightful way.

Second, the rhetoric of 'think family' appears to be translated, in practice, into a policy of 'think parenting'. Overwhelmingly, the axial relationships captured by these forms are the intergenerational relations of parents (or those acting in that role) and children. The aspirations of the Think Family policy statements to expand the understanding of family to take in further generations, various forms of siblinghood and extended relationships of uncles, aunts and cousins, appear to be constrained or obstructed by this focus on parent-child relations.

Third, an important constraint has been the development of many of these systems partly in response to, and wholly within a climate dominated by, concerns about children and families 'at risk'. This has led to the domination of bureaucratic models of risk minimisation that have positioned flexibility, ambiguity and professional judgement primarily as sources of potential risk and sought to manage them out of the system. Ironically, as 6 et al (2010) have persuasively argued, such attempts can be counterproductive, undermining the local, professional skills and judgements that are necessary for effective risk management. Rather than seeking prescriptive rules, they argue, public services should be 'cultivating sensitivities to risk, and ... enhancing skills in identifying and managing different kinds of risk, particularly in the context of training for, and local negotiations about, information-sharing practices in multi-agency working' (2010: 479; cf Baines et al, 2010; Munro, 2011).

Finally, the classifications and categories presented exclude the voices of family members - at least until state agencies have become deeply engaged with the case. The idea that families too might be able to contribute to the ways in which they are represented, that they might see and comment on the records in which they appear and that they might be able to raise concerns of their own, is substantially missing. If the state wishes to recruit families as allies, we might suggest that it will need to move beyond using information systems that treat them as objects to be administered.

This discussion highlights the need to examine more closely the effects of these systems on the kinds of families that it is possible to think and to support. Moreover, we also need to consider the processes by which the systems are developed. As Bourdieu (1996: 24) argued long ago, we need to ask 'who constructed the instruments of construction' and to examine family categories as 'institutions existing both in the objectivity of the world ... and in people's minds in the form of principles of classification that are implemented both by ordinary agents and by the licensed operators of official classifications'.

What is required here is not, we believe, a new 'one best way' or the application of a new expertise but rather a more sophisticated, empirically informed conversation that can take in voices and concerns from frontline professionals, public service managers, system designers and suppliers and, most importantly, families themselves.

\section{Conclusion: risky freedoms?}

What does this mean for the design of information and record systems? Previous work by the authors and others has shown some of the problems that the monopolisation of information and homogenisation of identity can bring (Richter and Cornford, 
2008; Wilson et al, 2011; Walsh et al, 2012). If we follow the drift of family studies and increasingly see family as something that one does, individually and collectively, rather than something that one has, then the haze might begin to clear somewhat. Families are not pre-given but negotiated in local contexts (Finch and Mason, 1993) and experienced through 'risky freedoms' (Beck and Beck-Gernsheim, 2004). From this perspective, then, the family is not 'the bedrock' of society, the substrata on which the rest of society is built, but rather a more or less conscious, more or less tenuous, outcome of action and interaction.

Instead of seeking a standardised set of descriptors for family - a grammar or ontology of family - which would enable a better description of an extant reality, what is required is a different kind of system, one that can support and record the processes of negotiation of family relationships and, very importantly, their 'risky freedoms'.

The precise technological and professional implications of this shift of perspective are complex - too complex to fully explore here - but they suggest that the model of technology that could underpin such a system would not look like the current database systems, based on notions of forms or records (eg Berg, 1996; 1999; Wilson et al, 2011; White et al, 2010; Hall et al, 2010). Rather, we propose that a new generation of systems needs to be agile and configurable in the hands of both professionals and lay users, supporting the active combination of elements of existing record systems but also supporting negotiation, project management (with parts of the system for planning and contingency), personal development planning (with parts for personal reflection and the production of curricula vitae) and social media approaches such as crowdsourcing and open data-linking techniques.

Finally, any alternative approach to representing the family also needs to draw on the sorts of 'systems' that families already know and make use of - 'family trees', 'family albums' and 'family heirlooms' - which are the materials in and with which transactions or conversations take place in the social representation of family membership (Chambers, 2001). If we were to move closer to a socio-technical model of the family, then what we need are tools that can help to support negotiation processes (including managing relationships and identity) among family members and between families, their members and the agents of the state in a governable manner where maintaining the separation of information is as important as integration (see Baines et al, 2010; Wilson et al, 2011; Walsh et al, 2012). Given we have established that there is no single view or point of truth about families, the development of such an information environment or infrastructure (Hanseth et al, 1996; McLoughlin and Wilson, 2012: forthcoming) might help in the effective negotiation of those risky freedoms that we need to really 'think family'. 


\section{References}

6, P., Bellamy, C. and Raab, C. (2010) 'Information-sharing dilemmas in public services: using frameworks from risk management', Policy \& Politics, 38 (3): 465-81.

Baines, S., Wilson, R. and Walsh, S. (2010) 'Seeing the full picture? Technologically enabled multi-agency working in health and social care', New Technology, Work \& Employment, 25 (1): 19-33.

Beck, U. and Beck-Gernsheim, E. (2004) 'Families in a runaway world', in J. Scott, J. Treas and M. Richards (eds) The Blackwell companion to the sociology of families, Oxford: Blackwell, 499-514.

Berg, M. (1996) 'Practices of reading and writing: the constitutive role of the patient record in medical work', Sociology of Health and Illness, 18: 499-524.

Berg, M. (1999) 'Patient care information systems and healthcare work: a sociotechnical approach', International Journal of Medical Informatics, 55: 87-101.

Bloomfield, B. and Vurdubakis, T. (1997) 'Visions of organisation and organisations of vision: The representational practices of information systems development', Accounting, Organisations and Society, 22(7): 639-668.

Bourdieu, P. (1996) 'On the family as a realized category', Theory, Culture \& Society, 13 (1): 19-26.

Bowker, G. and Star, S.L. (2002) Sorting things out: Classification and its consequences, Cambridge, MA: MIT Press.

Cabinet Office Social Exclusion Task Force (2007) Reaching out:Think family, London: Cabinet Office Social Exclusion Task Force.

Cabinet Office Social Exclusion Task Force (2008) Think family: Improving the life chances of families at risk, London: Cabinet Office Social Exclusion Task Force.

Cameron, D. (2011) Speech on the Big Society, Milton Keynes, 23 May [Online], www.number10.gov.uk/news/speech-on-the-big-society/

Chambers, D. (2001) Representing the family, London: Sage Publications.

Cheal, D. (1991) Family and the state of theory, London: Harvester Wheatsheaf.

Clarke, H. and Hughes, N. (2010) 'Introduction: family-minded policy and whole family practice - developing a critical research framework', Social Policy and Society, 9 (4): 527-31.

Clarke,J., Newman,J., Smith, N.,Vidler, E. and Westmarland, L. (2007) Creating citizenconsumers: Changing publics and changing public services, London: Sage Publications.

Connidis, I.A. and McMullin, J.A. (2002) 'Sociological ambivalence and family ties: a critical perspective', Journal of Marriage and the Family, 64 (3): 558-67.

DCSF (Department for Children, Schools and Families) (2009) Think family toolkit: Improving support for families at risk, London: DCSF.

DH (Department of Health), Department for Education and Employment and Home Office (2000) Framework for the assessment of children in need and their families, London: The Stationery Office.

Dourish, P. (2004) Where the action is:The foundations of embodied interaction, Cambridge, MA: MIT Press.

Edwards, R. and Gillies, V. (2012) 'Farewell to family? Notes on an argument for retaining the concept', Families, Relationships and Societies, 1 (1): 63-9.

Finch, J. and Mason, J. (1993) Negotiating family responsibilities, London: Routledge. 
Freeman, T., Jadva, V., Kramer, W. and Golombok, S. (2009) 'Gamete donation: parents' experiences of searching for their child's donor siblings and donor', Human Reproduction, 24 (3): 505-16.

Gillies,V. (2005) 'Meeting parents' needs? Discourses of "support” and "inclusion" in family policy', Critical Social Policy, 25 (1): 70-90.

Gittins, D. (1985) The family in question, Basingstoke: Macmillan.

Guijarro, L. (2007) 'Interoperability frameworks and enterprise architectures in egovernment initiatives in Europe and the United States', Government Information Quarterly, 24: 89-101.

Halford, S., Obstfelder, A. and Lotherington,A.-T. (2010) 'Changing the record: the inter-professional, subjective and embodied effects of electronic patient records', New Technology Work and Employment, 25 (3): 210-22.

Hall, C., Parton, N., Peckover, S. and White, S. (2010) 'Child-centric information and communication technology (ict) and the fragmentation of child welfare practice in England', Journal of Social Policy, 39 (3): 393-413.

Hanseth, O., Monteiro, E. and Hatling, M. (1996) 'Developing information infrastructure: the tension between standardization and flexibility', Science Technology Human Values, 21 (4): 407-26.

HM Government (2010), The Coalition: Our Programme for Government, London: Cabinet Office.

Holmes, J. and Kiernan, K. (2010) Fragile families in the UK: Evidence from the Millennium Cohort Study, www.york.ac.uk/media/spsw/documents/research-andpublications/HolmesKiernan2010FragileFamiliesInTheUKMillenniumCohort. pdf

Hutchins, E. (1995) Cognition in the wild, Cambridge, MA: MIT Press.

Kendall, S., Rodger, J. and Palmer, H. (2010) Redesigning provision for families with multiple problems: An assessment of the early impact of different local approaches, London: Department for Education.

King, S. and Cotterill, S. (2007) 'Transformational government? The role of information technology in delivering citizen-centric local public services', Local Government Studies, 33 (3): 333-54.

Laming, D. (2003) The Victoria Climbie Inquiry: Report of an inquiry by Lord Laming, Cm 5730, London: The Stationery Office.

Laming, D. (2009) The protection of children in England: A progress report, HC 330, London: The Stationery Office.

Lewis, J. (2007) 'Families, individuals and the state', in J. Hills, J. Le Grand and D. Piachaud (eds) Making social policy work, Bristol:The Policy Press, 59-84.

Lewis, J. (2011) 'From Sure Start to children's centres: an analysis of policy change in English early years programmes', Journal of Social Policy, 40 (1): 71-88.

Levi-Strauss, C. (1964) 'Structural analysis in linguistics and anthropology', in D. Hymes (ed) Language in Culture and Society, A Reader in Linguistics and Anthropology, New York: Harper and Row, 40-53.

Luescher, K. and Pillemer, K. (1998) 'Intergenerational ambivalence: a new approach to the study of parent-child relations in later life', Journal of Marriage and Family, 60 (2): 413-25.

McLoughlin, I. and Wilson, R. (2012: forthcoming)Digital government@work, Oxford: Oxford University Press. 
Milner, S. (2010) “"Choice” and "flexibility” in reconciling work and family: towards a convergence in policy discourse on work and family in France and the UK?', Policy \& Politics, 38 (1): 3-21.

Morgan, D. (2011) Rethinking family practices, Basingstoke: Palgrave Macmillan.

Morris, K. (2011) 'Thinking family? The complexities for family engagement in care and protection', British Journal of Social Work, advance access, 8 September 2011.

Mulkay, M. (1994) 'Science and family in the great embryo debate', Sociology, 28 (3): 699-715.

Munro, E. (2011) The Munro review of child protection: Final report: A child-centred system, Cm 8062,London:The Stationery Office, www.education.gov.uk/munroreview/ downloads/8875_DfE_Munro_Report_TAGGED.pdf

Prince, K. (1996) Boring records: Communication, speech and writing in social work, London: Jessica Kingsley Publishers.

Ribbens McCarthy, J. (2012) "The powerful relational language of "family": togetherness, belonging and personhood', The Sociological Review, 60 (1): 68-90.

Ribbens McCarthy, J. and Edwards, R. (2011) Key concepts in family studies, London: Sage Publications.

Richter, P. and Cornford, J. (2008) 'Customer relationship management and citizenship: technologies and identities in public services', Social Policy and Society, 7 (2): 211-20.

Scanzoni, J. (1987) 'Families in the 1980s: time to refocus our thinking', Journal of Family Issues, 8 (4): 394-421.

Schmid, J.E. and Pollack, S. (2009) 'Developing shared knowledge: family group conferencing as a means of negotiating power in the child welfare system', Practice, 21 (3): 175-88.

Shaw, I., Bell, M., Sinclair, I., Sloper, P., Mitchell,W., Dyson, P., Clayden, J. and Rafferty, J. (2009) 'An exemplary scheme? An evaluation of the integrated children's system', British Journal of Social Work, 39: 613-26.

Smart, C. (2005) 'Textures of family life: further thoughts on change and commitment', Journal of Social Policy, 34 (4):541-56.

Smart, C. (2007) Personal life: New directions in sociological thinking, Cambridge: Polity Press.

Smith, D.E. (1993) 'The standard North American family: SNAF as an ideological code', Journal of Family Issues, 14 (1): 50-65.

Star, S.L. and Griesemer, J.R. (1989) 'Institutional ecology, "translations," and boundary objects: amateurs and professionals in Berkeley's Museum of Vertebrate Zoology, 1907-1939', Social Studies of Science, 19: 387-420.

Strathern, M. (1996) 'Enabling identity? Biology, choice and the new reproductive technologies', in S. Hall and P. du Gay (eds) Cultural identity, London: Sage Publications, 37-52.

Therborn, G. (2004) Between sex and power: Family in the world 1900-2000,Abingdon: Routledge.

Walsh, S., Wilson, R., Baines, S. and Martin, M. (2012) “'You're just treating us as informants!'Roles, responsibilities and relationships in the production of children's services directories, Local Government Studies, 38 (6), e-publication ahead of print.

Wheeler, B. (2005) 'Who are "Britain's hardworking families”?', BBC website, http:// news.bbc.co.uk/1/hi/uk_politics/vote_2005/frontpage/4458273.stm 
White, C., Warrener, M., Reeves, A. and LaValle, I. (2009) Family intervention projects: An evaluation of their design, set-up and early outcomes, Research Report No DCSFRW047, London: Department for Children, Schools and Families.

White, S., Wastell, D., Broadhurst, K. and Hall, C. (2010) 'When policy o'erleaps itself: the "tragic tale" of the Integrated Children's System', Critical Social Policy, 30 (3): 405-29.

White,T. and Ettner, R. (2007) 'Adaptation and adjustment in children of transsexual parents', European Child and Adolescent Psychiatry, 16: 215-21.

Williams, F. (2004) Rethinking families, London: Calouste Gulbenkian Foundation.

Wilson, A.R. (2007) 'With friends like these: the liberalization of queer family policy', Critical Social Policy, 27 (1): 50-76.

Wilson, R., Martin, M., Walsh, S. and Richter, P. (2011) 'Re-mixing the digital economies of care in the voluntary and community sector (VCS): governing identity and information sharing in the mixed economy of care for children and young people', Social Policy and Society, 10 (3): 379-91.

Woolgar, S. (1995) 'Representation, cognition and the self: what hope from an integration of psychology and sociology', in S. Leigh Star (ed) Ecologies of knowledge: Work and politics in science and technology, New York, NY: SUNY Press, 154-80.

York Consulting (2011) Turning around the lives of families with multiple problems: An evaluation of the Family and Young Carer Pathinders Programme, London:Department for Education.

James Cornford (j.cornford@uea.ac.uk)

Norwich Business School, University of East Anglia, Norwich, UK

\section{Susan Baines}

The Centre for Enterprise, Manchester Metropolitan University Business School, Manchester, UK

\section{Rob Wilson}

Centre for Knowledge, Innovation, Technology and Enterprise, Newcastle University Business School, Newcastle upon Tyne, UK 